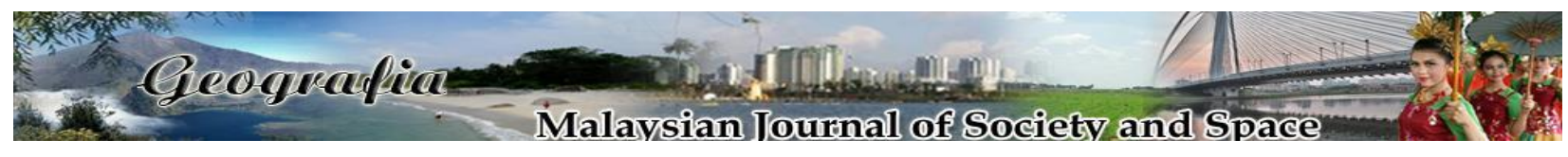

\title{
Kesedaran kesihatan mempengaruhi kadar penuaan di bandaraya Kuala Lumpur
}

\author{
Farah Elisha Mohd Adnand ${ }^{1}$, Rosniza Aznie Che Rose ${ }^{1}$, Kadaruddin Aiyub ${ }^{1}$, Novel Lyndon², \\ Mohd Yusof Hussain ${ }^{3}$ \\ ${ }^{1,2,3}$ Program Geografi, Pusat Kajian Pembangunan, Sosial dan Persekitaran, Fakulti Sains Sosial dan \\ Kemanusiaan, Universiti Kebangsaan Malaysia, Bangi, Selangor \\ ${ }^{2}$ Program ANSOS, Pusat Kajian Pembangunan, Sosial dan Persekitaran, Fakulti Sains Sosial dan \\ Kemanusiaan, Universiti Kebangsaan Malaysia, Bangi, Selangor \\ ${ }^{3}$ Program Sains Pembangunan, Pusat Kajian Pembangunan, Sosial dan Persekitaran, Fakulti Sains Sosial \\ dan Kemanusiaan, Universiti Kebangsaan Malaysia, Bangi, Selangor \\ Correspondence: Rosniza Aznie Che Rose (email: aznie@ukm.edu.my)
}

Received: 26 April 2021; Accepted: 17 August 2021; Published: 27 August 2021

\begin{abstract}
Abstrak
Malaysia dijangka mendapat status negara tua pada tahun 2030. Penuaan penduduk berlaku apabila penambahan jangka hayat penduduk dan berlakunya penurunan kadar kesuburan. Peningkatan jumlah warga tua adalah hasil daripada perkembangan kemudahan kesihatan, kemajuan teknologi, kesedaran penduduk terhadap kepentingan penjagaan kesihatan, peningkatan taraf pendidikan, dan pekerjaan. Artikel ini membincangkan tentang kesedaran kesihatan mempengaruhi kadar penuaan di Bandaraya Kuala Lumpur. Kajian ini memberi fokus tentang penggunaan kemudahan fasiliti awam kesihatan penduduk di kawasan Bandaraya Kuala Lumpur. Kaedah kuantitatif telah digunakan dalam kajian ini dan populasi kajian adalah warga tua yang berumur 60 tahun ke atas berdasarkan takrifan yang dibuat oleh Jabatan Kebajikan Masyarakat. Persampelan yang digunakan dalam kajian ini ialah persampelan bertujuan. Kriteria penerimaan sampel warga tua yang berumur 60 tahun ke atas, mampu memahami dan melengkapkan borang soal selidik. Analisis deskriptif iaitu peratus dan min telah digunakan. Dapatan kajian menunjukkan kemudahan awam, amalan kesihatan dan kesihatan umum merupakan keperluan utama bagi warga emas bandar dalam memastikan mereka dapat menjalani kehidupan seharian dengan baik. Oleh itu, kajian ini boleh dimanfaatkan oleh semua pihak bagi tujuan memperkasa pembangunan fasiliti awam mesra warga tua bandar.
\end{abstract}

Kata kunci: Kemudahan kesihatan, penuaan, rakyat Malaysia, warga emas 


\title{
Health awareness affecting ageing trend in Kuala Lumpur
}

\begin{abstract}
Malaysia is anticipated to be designated as an old country by 2030 . When the population's life expectancy rises but fertility rates fall, population ageing occurs. This article discusses how health awareness influences the rate of ageing in Kuala Lumpur City. This study focuses on the use of public health facilities in the Kuala Lumpur City area. The population of the study consisted of the elderly aged 60 and above, and quantitative methodologies were applied. Purposive sampling was employed in this investigation. Acceptance criteria for a sample of elderly persons aged 60 and above who can understand and complete the survey. Percentage and mean were utilised in the descriptive analysis. The study's findings suggest that public facilities, health practises, and public health are the most important demands for urban elderly persons in order for them to be able to live well in their daily lives. As a result, all parties can benefit from this research in order to encourage the development of elderly-friendly public amenities in cities.
\end{abstract}

Keywords: Health facilities, aging, Malaysians, senior citizen

\section{Pengenalan}

Realiti penuaan penduduk yang berlaku tidak dapat dinafikan dan setiap insan bernyawa di dunia akan merasainya. Oleh itu, setiap negara terutamanya negara Malaysia perlu bersedia untuk menghadapi penuaan penduduk. Penuaan penduduk ini berlaku apabila berlakunya peningkatan warga emas (Kementerian Kesihatan Malaysia, 2016) sama ada bertambah angka sebenar atau bertambah kadarnya dalam sebuah negara. Manakala menurut Heryanah (2015) penuaan penduduk ini berlaku apabila pertambahan jangka hayat penduduk dan penurunan kadar kesuburan. Proses semula jadi penuaan yang dialami di dunia kini tidak dapat dicegah, iaitu setiap orang berharap dapat menjalani kehidupan yang lebih sihat, tenang, penuh kasih sayang dan menikmati waktu tua bersama orang yang dicintai (Siti et al., 2019).

Warga tua atau warga emas ini terdiri daripada golongan yang berusia 60 tahun dan ke atas (Jabatan Kebajikan Masyarakat, 2017). Malaysia akan menerima rakyat dua kali ganda daripada jumlah penduduk yang berumur 60 tahun ke atas pada tahun 2030 (Idris, 2017) dan Malaysia akan menjadi negara tua akibat berlakunya kemerosotan kadar kesuburan dan jangka hayat rakyat Malaysia lebih panjang (Khadijah \& Maizatul, 2017). Menurut Nurhazirah dan Khadijah (2021) jumlah warga emas telah menunjukkan pertambahan dari 9.24 peratus pada tahun 2015 meningkat kepada 11.1 peratus pada tahun 2020. Mengikut jangkaan Persatuan Bangsa-Bangsa Bersatu (PBB) pada tahun 2030, Malaysia akan mencapai 15 peratus daripada jumlah penduduk apabila berumur 60 tahun ke atas. Hal ini selaras dengan Dasar Warga Emas Negara yang dikemukakan oleh pihak Kementerian Pembangunan Wanita, Keluarga dan Masyarakat (KPWKM) iaitu apabila penduduk telah mencecah 15 peratus daripada jumlah penduduk yang berumur 60 tahun atau 7 peratus jumlah keseluruhan populasi penduduk yang berumur 65 tahun ke atas (Kementerian Kesihatan Malaysia, 2016). Penyediaan perkhidmatan kepada warga emas dan kemudahan kepada mereka merupakan tunjang utama dasar ini dibangunkan di Malaysia (Ahmad Shukri \& Norliza, 2018). 
Peningkatan taraf hidup penduduk di negara Malaysia dengan negara maju yang lain sangat berbeza iaitu negara Malaysia mencapai status negara tua lebih cepat. Hal ini demikian kerana keperluan dan kebajikan warga tua telah diberi perhatian melalui penubuhan satu unit kementerian iaitu KPWKM. Penubuhan Unit Kebajikan Masyarakat ini secara tidak langsung akan menyumbang peningkatan kualiti hidup dan kesejahteraan warga tua di Malaysia. Ketenteraman warga tua atau warga emas di kawasan bandar dilihat lebih selesa, aman dan mempunyai kualiti hidup yang lebih terjamin. Keterbatasan umur warga tua menjadi satu permasalahan kepada mereka apabila mereka dinasihatkan untuk berehat dan menikmati hari-hari tua mereka tanpa memikirkan soal kerja. Walau bagaimanapun, tanggapan ini adalah salah kerana warga tua juga berhak bergiat aktif dalam pelbagai aktiviti untuk membantu pembangunan negara.

Seterusnya, bagi penyediaan menghadapi peningkatan warga tua di Malaysia, pelbagai perkhidmatan yang telah disediakan oleh kerajaan mahupun badan bukan kerajaan bagi menjaga kesejahteraan dan ketenteraman warga tua. Antaranya inisiatif yang dilakukan adalah kemudahan kesihatan seperti mendapatkan kad diskaun warga dan warga emas ini akan mendapatkan laluan khas bagi penggunaan hospital atau klinik kesihatan kerajaan sekiranya warga emas ini mendapatkan rawatan. Dengan cara ini, ia menggalakkan warga emas mendapatkan rawatan dan lebih gemar ke hospital atau klinik kesihatan kerajaan untuk mendapatkan rawatan. Malahan, kehidupan sekeliling warga tua juga memainkan peranan. Menurut Shaista et al. (2019) penduduk warga tua adalah masyarakat campuran dan mengalami pelbagai faktor kesihatan. Oleh itu, penduduk berumur ini memerlukan perumahan, dilengkapi dengan teknologi agar kehidupan mereka dapat dinikmati dengan lebih selesa dan aman.

Kemajuan kesihatan yang dicapai oleh sesebuah negara adalah hasil daripada peningkatan warga tua di negara ini (Azura \& Suresh, 2019). Peningkatan warga tua, telah menyebabkan kos perubatan turut meningkat bersama-sama dengan kemajuan teknologi yang lebih baik dalam bidang sains perubatan. Menurut Schulte et al. (2015) walaupun sistem penjagaan kesihatan di Malaysia adalah memuaskan namun isu mengenai kemampuan dan kualiti semakin teruk. Peningkatan warga tua juga akan memberikan masalah kesihatan kepada mereka yang kurang aktif. Hal ini demikian kerana akan berlakunya penurunan kualiti hidup warga tua dan meningkatkan masalah kesihatan orang tua terutamanya gangguan kesihatan mental dan emosi (Muhammad Nur \& Hamid, 2020). Oleh itu kebajikan terhadap warga tua adalah sangat penting kerana keterbatasan mereka dalam melakukan pekerjaan dan kehendak yang mereka perlukan.

Akhir sekali, keterbatasan mereka dalam melakukan pekerjaan akan memberi satu kesukaran kepada warga emas, ditambah lagi dengan kemudahan fasiliti awam bandar yang tidak mampu memenuhi keselesaan menyeluruh kepada warga emas. Sebagai contoh keterbatasan aktiviti fizikal, masalah kesihatan yang perlu menjalani rawatan secara berkala dan tidak aktif. Menurut Bose dan Banerjee (2019) keperluan penjagaan kesihatan telah menimbulkan kebimbangan besar terhadap populasi yang berumur. Tujuan kajian ini adalah untuk mengenal pasti tahap kesedaran penggunaan kemudahan dan amalan kesihatan dalam kalangan warga tua di Bandaraya Kuala Lumpur. Untuk itu, dengan mengambilkira keperluan memperkasa hidup warga tua bandar, kesedaran terhadap kemudahan kesihatan bandar sudah pasti merupakan satu usaha dan manfaat bersama bagi tempoh jangka masa yang panjang. 


\section{Kajian Literatur}

Kesedaran terhadap kemudahan awam memainkan peranan penting kepada warga tua bagi menjalankan urusan seharian mereka. Kemudahan awam ditakrifkan sebagai tindak balas institusi kepelbagaian manusia yang memainkan peranan penting dalam memberi perkhidmatan sokongan untuk mewujudkan kehidupan yang berdaya maju bagi masyarakat yang bersatu (Alice et al., 2019). Tedapat empat jenis kemudahan awam yang biasa digunakan iaitu kemudahan kesihatan, keselamatan, pendidikan dan rekreasi (Alice et al., 2019). Kajian yang dilakukan di China, keperluan warga emas terhadap kemudahan perkhidmatan kesihatan harus disediakan. Menurut Liqun et al. (2019) perkhidmatan penjagaan kesihatan warga emas dianggap paling penting berbanding dengan bantuan kehidupan, hiburan dan keperluan mengenai pemulihan. Kajian yang dilakukan di Korea juga mendapati perkhidmatan kesihatan atau perkhidmatan kejururawatan telah berkembang dengan pesat kerana berlakunya peningkatan mendadak jumlah warga emas (Huh \& Kim, 2019). Ini disebabkan oleh kesukaran warga emas untuk mendapatkan perkhidmatan rawatan kesihatan kerana tidak mudah bagi warga emas untuk mencari pusat rawatan kesihatan yang mudah diakses dan mencukupi yang memenuhi keperluan mereka (Huh \& Kim, 2019).

Sementara itu, Qin Wang (2019) menyatakan terdapat tiga jenis masalah utama warga emas terhadap penggunaan kemudahan awam. Pertama, maklumat awam tentang perkhidmatan kepada penggunaan warga tua adalah tidak mencukupi. Kedua kesukaran untuk warga tua untuk menggunakan perkhidmatan layan diri di terminal dan ketiga pengkhususan produk awam bukan diberikan tumpuan kepada warga emas tetapi lebih tertumpu kepada golongan remaja. Kekurangan akses terhadap maklumat ini telah menyukarkan pengguna terutamanya kepada golongan warga emas. Berbeza dengan kajian yang dilakukan di Hong Kong, kemudahan seperti tambang dan tempat duduk adalah mencukupi. Menurut Wong et al. (2018), kemudahan perlu diberikan keutamaan bagi mempengaruhi keselesaan warga emas. Hal ini demikian kerana penyediaan kemudahan yang baik dan mementingkan aspek keselamatan akan meningkatkan lagi warga emas menggunakan kemudahan dengan selamat dan selesa (Wong et al., 2018).

\section{Metod dan Kawasan Kajian}

Reka bentuk kajian yang digunakan ialah kajian tinjauan kerana memfokuskan kepada pandangan warga emas terhadap keberkesanan kemudahan awam terhadap mereka. Kajian tinjauan sesuai digunakan kerana kaedah ini sesuai untuk ditadbir dalam masa yang terhad. Persampelan bertujuan telah digunakan kerana ini sesuai dengan penyelidikan yang dilakukan iaitu melibatkan warga emas yang berumur 60 tahun ke atas. Selain itu, kajian ini dilakukan menggunakan kaedah kuantitatif sebagai kaedah utama. Instumen dalam kajian ini soal selidik sebagai alat kajian bertujuan untuk memperoleh dalam bentuk ukuran kuantitatif. Instumen soal selidik ini merangkumi empat bahagian utama. Bahagian A mengandungi enam item iaitu melibatkan maklumat demografi responden. Bahagian B pula mengandungi 11 item yang berkaitan dengan penggunaan kemudahan kesihatan. Seterusnya, pada Bahagian C pula, melibatkan empat item iaitu amalan kesihatan dan Bahagian D pula, mengandungi lima item yang melibatkan kesihatan umum.

Hasil data dianalisis dengan menggunakan analisis deskriptif (peratus dan min). Kajian ini menggunakan skala Likert lima mata. Pengkaji menggunakan nilai min yang yang dikemukakan oleh Nurnally dan Bernstein (1994). Skor min 1.00 hingga 2.00 iaitu rendah, manakala 2.01 hingga 3.00 pula sederhana rendah, 3.01 hingga 4.00 adalah sederhana tinggi dan akhir sekali 4.01 hingga 
5.00 adalah tinggi. Item yang terdapat di dalam borang soal selidik akan dipersembahkan dalam jadual di bahagian hasil analisis. Populasi kajian melibatkan warga tua yang tinggal di Bandaraya Kuala Lumpur. Sampel kajian digunakan dalam kajian ini adalah seramai 100 orang. Pemilihan sampel ini berdasarkan pengiraan survery software dan rules of thumb. Hal ini bermakna seramai 100 orang sudah mewakili populasi warga emas yang tinggal di Bandaraya Kuala Lumpur.

Bandaraya Kuala Lumpur dijadikan sebagai fokus kajian kerana bandaraya ini merupakan bandaraya yang terbesar di Malaysia dan sebahagian besar meliputi negeri Selangor. Malah Kuala Lumpur menyumbang jumlah penduduk paling ramai berbanding bandar yang lain kerana Kuala Lumpur ini merupakan ibu negara Malaysia dan bandar metropolitan yang menjadi salah satu pusat tumpuan orang ramai. Proses pembandaran yang berlaku begitu pesat di negara ini dari segi sektor ekonomi, bandar ini merupakan pilihan dalam kalangan penduduk di Asia Tenggara. Hal ini demikian kerana Bandaraya Kuala Lumpur dipenuhi dengan pelbagai kemudahan dan prasarana yang mampu memenuhi keperluan penduduk.

\section{Dapatan kajian}

\section{Latar belakang responden}

Berdasarkan Jadual 1 menunjukkan secara keseluruhan bagi kategori latar belakang responden penduduk iaitu jantina, status, etnik, agama, tahap pendidikan tertinggi dan pekerjaan.

Jadual 1. Latar belakang responden.

\begin{tabular}{|c|c|c|c|}
\hline \multirow[t]{2}{*}{ Kategori } & \multirow[t]{2}{*}{ Subkategori } & \multicolumn{2}{|c|}{ Warga tua } \\
\hline & & Bilangan & Peratus (\%) \\
\hline \multirow[t]{2}{*}{ Jantina } & Lelaki & 63 & 63 \\
\hline & Perempuan & 32 & 32 \\
\hline \multirow[t]{3}{*}{ Status } & Berkahwin & 83 & 83 \\
\hline & Bercerai atau Berpisah & 2 & 2 \\
\hline & Duda atau Balu & 15 & 15 \\
\hline \multirow[t]{4}{*}{ Etnik } & Melayu & 76 & 76 \\
\hline & Cina & 15 & 15 \\
\hline & India & 7 & 7 \\
\hline & Lain-lain & 2 & 2 \\
\hline \multirow[t]{4}{*}{ Agama } & Islam & 79 & 79 \\
\hline & Buddha & 10 & 10 \\
\hline & Hindu & 9 & 9 \\
\hline & Kristian & 2 & 2 \\
\hline \multirow[t]{8}{*}{ Tahap Pendidikan } & $\begin{array}{c}\text { Penilaian Darjah Lima } \\
\text { atau UPSR }\end{array}$ & 15 & 15 \\
\hline & LCE/SRP/PMR & 17 & 17 \\
\hline & MCE/SPM/O Level & 42 & 42 \\
\hline & STPM/STP/HSC/A & 4 & 4 \\
\hline & Level/ Diploma & & \\
\hline & Sarjana Muda & 16 & 16 \\
\hline & Sarjana/PHD & 1 & 1 \\
\hline & Lain-lain & 4 & 4 \\
\hline \multirow[t]{3}{*}{ Pekerjaan } & Bekerja (Awam) & 5 & 5 \\
\hline & Bekerja (Swasta) & 35 & 35 \\
\hline & Bersara & 60 & 60 \\
\hline
\end{tabular}

Sumber: Kajian Lapangan 2020 


\section{Penggunaan kemudahan dan amalan kesihatan}

Pada bahagian ini analisis kajian adalah untuk meneliti kekerapan warga emas terhadap penggunaan kemudahan kesihatan dan amalan kesihatan yang digunakan. Skala Likert telah digunakan dalam kajian ini. Walau bagaimanapun, pada bahagian ini pengkaji telah meringkaskan daripada hasil yang diperoleh kepada nilai min dan sisihan piawai. Berdasarkan jumlah responden, kekerapan bagi warga emas perempuan ialah 37 orang dan kekerapan bagi warga emas lelaki pula ialah 63 orang.

Jadual 2 menunjukkan tentang analisis item bagi item-item pemboleh ubah kemudahan kesihatan awam yang mempengaruhi kehidupan warga emas. Terdapat 11 item yang menilai pengaruh penggunaan kemudahan kesihatan terhadap kemudahan fasiliti awam bagi warga emas. Item yang menonjol dalam analisis kajian ini menunjukkan pandangan warga emas terhadap kemudahan kesihatan dan amalan kesihatan mempengaruhi tahap kesihatan warga emas. Berdasarkan kesemua item tersebut nilai min yang dicatatkan paling rendah ialah item A8 $(\mathrm{M}=2.35, \mathrm{SP}=1.266)$, manakala item A4 merupakan nilai min yang paling tinggi $(\mathrm{M}=4.43$, $\mathrm{SP}=0.685)$. Daripada analisis tersebut, purata min keseluruhan bagi kesemua item penggunaan kemudahan kesihatan ialah $\mathrm{M}=3.76$ dan $\mathrm{SP}=0.925$. Oleh itu, pengkaji membuat interpretasi bahawa berdasarkan purata yang diperoleh item penggunaan kemudahan kesihatan bagi warga emas berada pada tahap sederhana tinggi.

Jadual 2. Min dan sisihan piawai bagi item-item penggunaan kemudahan kesihatan.

\begin{tabular}{lcc}
\hline Item & M & SP \\
\hline A1 Saya mendapati hospital/ klinik kesihatan kerajaan sangat mesra & 4.20 & 0.696 \\
$\begin{array}{l}\text { A2 Saya mendapati hospital/ klinik kesihatan kerajaan adalah mudah diakses } \\
\text { daripada rumah }\end{array}$ & 4.02 & 0.829 \\
$\begin{array}{l}\text { A3 Saya mendapati doktor/ pembantu hospital/ jururawat dan lain-lain sangat } \\
\text { perihatin terhadap pesakit yang terdiri daripada warga tua }\end{array}$ & 4.22 & 0.733 \\
$\begin{array}{l}\text { A4Saya mendapatkan rawatan kesihatan di hospital/ klinik kesihatan kerajaan } \\
\text { kerana ia murah }\end{array}$ & 4.43 & 0.685 \\
$\begin{array}{l}\text { A5 Saya mendapatkan rawatan kesihatan di hospital/ klinik kesihatan kerajaan } \\
\text { kerana ia mudah }\end{array}$ & 4.14 & 0.853 \\
$\begin{array}{l}\text { A6 Saya mendapatkan rawatan kesihatan di hospital/ klinik kesihatan kerajaan } \\
\text { kerana ia menepati masa }\end{array}$ & 3.25 & 1.048 \\
$\begin{array}{l}\text { A7 Saya mendapatkan rawatan kesihatan di hospital/ klinik kesihatan kerajaan } \\
\text { kerana ia sentiasa memantau kehadiran temujanji saya }\end{array}$ & 3.94 & 0.962 \\
$\begin{array}{l}\text { A8 Saya tahu menggunakan aplikasi emel, sms dan web bagi tujuan penghantaran } \\
\text { ubat ke rumah }\end{array}$ & 2.35 & 1.266 \\
$\begin{array}{l}\text { A9 Saya mendapati hospital/ klinik kesihatan kerajaan adalah yang terbaik } \\
\text { A10 Saya mendapat kad diskaun warga emas bagi penggunaan hospital/ klinik } \\
\text { kesihatan kerajaan }\end{array}$ & 3.87 & 0.872 \\
$\begin{array}{l}\text { A11 Saya mendapat laluan khas bagi penggunaan hospital/ klinik kesihatan } \\
\text { kerajaan }\end{array}$ & 3.38 & 1.138 \\
\hline Purata & 3.76 & 0.925 \\
\hline
\end{tabular}

Jadual 3 pula menunjukkan analisis terhadap pemboleh ubah amalan kesihatan keluarga yang diamalkan oleh warga emas. Berdasarkan nilai min yang paling rendah ialah B2 (M=2.89, SP=1.270). Manakala bagi nilai min yang paling tinggi yang dicatatkan ialah $\mathrm{B} 3(\mathrm{M}=4.47, \mathrm{SP}=0.716)$. Daripada analisis tersebut, nilai keseluruhan bagi semua item amalan kesihatan keluarga ialah $\mathrm{M}=3.51$ dan $\mathrm{SP}=0.916$. Oleh itu, purata yang diperoleh oleh item amalan kesihatan keluarga adalah berada pada tahap sederhana tinggi. 
Jadual 3. Min dan sisihan piawai bagi item-item amalan kesihatan keluarga.

\begin{tabular}{lcc}
\hline Item & M & SP \\
\hline B1 Hidangan harian kami adalah seimbang & 3.75 & 0.744 \\
$\begin{array}{l}\text { B2 Ahli keluarga kami tiada yang berpenyakit kronik (cth. Kencing manis, } \\
\text { darah tinggi, sakit jantung, barah dan lain-lain) }\end{array}$ & 2.89 & 1.270 \\
$\begin{array}{l}\text { B3 Keluarga kami bebas daripada masalah penyalahgunaan bahan (cth. Dadah, } \\
\text { alkohol, gam, daun ketum, ganjal dan lain-lain) }\end{array}$ & 4.47 & 0.716 \\
B4 Kami sekeluarga bersenam sekurang-kurangnya tiga kali seminggu & 2.93 & 0.934 \\
\hline Purata & 3.51 & 0.916 \\
\hline
\end{tabular}

Jadual 4 pula menunjukkan analisis terhadap pemboleh ubah kesihatan umum bagi warga emas. Berdasarkan nilai min terendah bagi kesemua item-item kesihatan umum ialah item C3 $(\mathrm{M}=1.70, \mathrm{SP}=0.664)$ dan nilai min tertinggi pula menunjukkan item $\mathrm{C} 4(\mathrm{M}=4.06, \mathrm{SP}=0.664)$. Daripada analisis tersebut, purata min keseluruhan bagi kesemua item kesihatan umum ialah $\mathrm{M}=3.19$ dan $\mathrm{SP}=0.813$. Secara keseluruhan, purata bagi kesemua item kesihatan umum bagi warga emas adalah pada tahap sederhana tinggi.

Jadual 4. Min dan sisihan piawai bagi item-item kesihatan umum.

\begin{tabular}{lcc}
\hline Item & M & SP \\
\hline C1 Kurang tidur kerana risau & 2.28 & 1.1074 \\
C2 Diri tidak berguna & 1.70 & 0.905 \\
C3 Boleh menumpukan perhatian & 3.94 & 0.664 \\
C4 Dapat menikmati aktiviti harian & 4.06 & 0.664 \\
C5 Dalam apa jua keadaan, saya masih berasa gembira & 3.96 & 0.724 \\
\hline Purata & 3.19 & 0.813 \\
\hline
\end{tabular}

\section{Perbincangan}

\section{Kemudahan kesihatan}

Penggunaan kemudahan kesihatan bagi golongan warga emas atau warga tua memainkan peranan penting. Hal ini demikian kerana ia bergantung kepada tahap kemesraan kemudahan kesihatan terhadap warga emas. Berdasarkan kajian yang diperoleh di lapangan mendapati responden setuju bahawa penggunaan kemudahan kesihatan hospital atau klinik kesihatan kerajaan sangat mesra warga tua iaitu sebanyak 60 peratus dan hanya empat peratus responden sahaja yang menyatakan sangat tidak setuju dengan kenyataan tersebut. Hal ini demikian kerana ia sangat bergantung kepada kemudahan yang mudah untuk diakses. Menurut Manang dan Yamauchi (2018), perkembangan atau peningkatan terhadap sesuatu infrastruktur akan memudahkan seseorang untuk mengakses kemudahan berkenaan dengan lebih baik. Sebagai contoh di Uganda, penggunaan kemudahan kesihatan yang dapat diakses telah memberikan kesan yang positif kepada pengguna. Malah berbeza dengan kajian yang dilakukan di Kenya, penduduk miskin yang tinggal di bandar dan luar bandar sering menghadapi halangan dan cabaran untuk mendapatkan kemudahan akses yang mencukupi untuk mendapatkan rawatan kesihatan yang berkualiti. Bahkan, sebilangan penduduk pula tidak mendapat kemudahan akses yang baik disebabkan masa menunggu yang lama, kekurangan bekalan keperluan dan mereka menganggap kualiti perkhidmatan di hospital kerajaan sangat rendah (Escamilla et al., 2019). Seterusnya, sebanyak 50 
peratus bersetuju bahawa penggunaan kemudahan kesihatan mendapati hospital atau klinik kesihatan kerajaan adalah mudah diakses daripada rumah. Menurut Khadijah Alavi dan Maizatul (2017), pendidikan secara formal atau informal kurang didedahkan kepada anak-anak dan orang dewasa terutamanya cara menjaga dan merawat orang tua yang uzur atau menghidap penyakit kronik. Oleh itu, penggunaan kemudahan kesihatan sukar dijalankan dan dilakukan di rumah.

Selain itu, doktor atau pembantu hospital memainkan peranan penting apabila mengendalikan pesakit terutamanya golongan yang berumur 60 tahun ke atas. Berdasarkan kajian yang diperoleh mendapati doktor atau pembantu hospital atau jururawat dan lain-lain sangat prihatin terhadap pesakit yang terdiri daripada warga tua. Sebanyak 53 peratus responden setuju dengan kenyataan dan hanya satu peratus sahaja yang menyatakan sangat tidak setuju. Hal ini demikian kerana warga tua ini sangat sensitif dan mudah terasa. Peranan doktor atau pembantu hospital dapat memujuk warga tua ini dalam mendapatkan rawatan yang lebih baik di hospital. Menurut Berstad et al. (2016) berdasarkan kajian yang dilakukan bagi mengelak berlakunya kematian awal dan meningkatkan jangka hayat, melalui saranan doktor ia akan memberi kebaikan kepada golongan dewasa pertengahan usia. Hal ini menunjukkan bahawa saranan daripada doktor dapat memberikan keyakinan kepada warga tua untuk mendapatkan rawatan lagi. Malah rawatan yang diberikan oleh hospital sangat murah dan berpatutan. Hasil kajian yang menunjukkan responden sangat setuju dengan kenyataan mendapatkan rawatan kesihatan di hospital atau klinik kesihatan kerana ia murah iaitu sebanyak 52 peratus dan peratus terendah iaitu sebanyak dua peratus yang tidak setuju dengan kenyataan tersebut. Bayaran dalam perubatan yang berpatutan akan memberikan satu kepuasan kepada pesakit dan mereka akan berpuas hati (Jinming et al., 2019).

Seterusnya, rawatan kesihatan di hospital atau klinik kesihatan kerajaan ia sentiasa memantau kehadiran warga tua. Berdasarkan kajian yang diperoleh menunjukkan bahawa peratus tertinggi yang sangat setuju dengan kenyataan tersebut ialah 44 peratus dan peratus terendah pula sebanyak tiga peratus. Pemantauan warga tua di hospital memudahkan mereka untuk mendapatkan rawatan yang lebih baik. Walau bagaimanapun, berbeza dengan kajian yang dilakukan di Jepun terhadap warga tua, mereka memantau kehadiran warga tua disebabkan golongan ini (warga tua) kurang peka terhadap pengambilan ubat-ubatan (Takeshi et al., 2019). Hal ini secara tidak langsung menyebabkan berlakunya peningkatan penyalahgunaan dadah dalam ubat-ubatan yang diberikan dan hospital terpaksa memantau dengan teliti terhadap golongan ini. Malah peratus tertinggi dan terendah mendapati hospital atau klinik kesihatan kerajaan adalah terbaik iaitu sebanyak 51 peratus menyatakan setuju dan hanya dua peratus menyatakan sangat tidak setuju. Hal ini demikian menunjukkan bahawa kemudahan yang disediakan dapat dimanfaatkan oleh warga tua.

Seterusnya, kemudahan kesihatan terutamanya kepada warga tua atau warga emas seperti kad diskaun sangat memainkan peranan penting. Hal ini demikian kerana warga tua atau warga emas kerap ke hospital dalam mendapatkan rawatan. Peratusan tertinggi menyatakan setuju bahawa mereka mendapatkan kad diskaun warga emas bagi penggunaan hospital atau klinik kesihatan kerajaan iaitu sebanyak 34 peratus setuju dengan kenyataan dan peratus terendah pula ialah lima peratus sangat tidak setuju. Malah kerajaan Malaysia juga telah memperuntukkan bantuan khusus kepada warga tua iaitu sebanyak RM 350 sebulan. Tujuan utama bantuan diberikan untuk meneruskan kelangsungan hidup dan menjamin kesejahteraan hidup dalam komuniti (Jabatan Kebajikan Masyarakat, 2017). Malah kajian dilakukan di India, golongan miskin mendapat faedah subsidi awam terutamanya kepada warga tua dari segi mendapatkan perubatan kerana di kawasan bandar pesakit dalam dan pesakit luar, kelas termiskin mempunyai bahagian 
yang besar dalam penggunaan kemudahan awam. Faedah subsidi ini mengurangkan bebanan kepada warga emas bagi menggunakan kemudahan kesihatan. Ini menunjukkan bahawa polisi yang disasarkan untuk warga tua diperlukan untuk meningkatkan penggunaan dan keadilan dalam sistem penjagaan kesihatan awam (Bose \& Banerjee, 2019).

Akhir sekali, Jabatan Kebajikan Malaysia telah menyediakan program Unit Penyayang Warga Emas (UPWE). Program ini merupakan salah satu inisiatif kerajaan Malaysia membantu warga emas untuk mendapatkan pertolongan sama ada kemudahan dan juga memberi perkhidmatan. Objektif yang terkandung dalam program UPWE ini telah menggalakkan lagi warga emas untuk mendapatkan kemudahan yang disediakan khusus diberikan kepada warga emas untuk meringankan beban pergerakan. Berdasarkan kajian yang dilakukan bahawa warga emas mendapat laluan khas bagi penggunaan hospital atau klinik kesihatan kerajaan menunjukkan peratus tertinggi dan peratus terendah iaitu masing-masing sebanyak 38 peratus responden setuju dan sebanyak lima peratus sangat tidak setuju. Menurut Mohd Farok et al. (2021), laluan khas harus diberikan kepada warga emas bagi memudahkan mereka untuk mengakses kemudahan dengan mudah. Malahan, potensi faedah untuk memberikan keselesaan kepada warga emas tercapai.

\section{Amalan kesihatan keluarga}

Amalan kesihatan keluarga memainkan peranan penting. Hal ini demikian kerana kesihatan keluarga dapat melahirkan komuniti yang sejahtera (Amran et al., 2012). Berdasarkan kenyataan bahawa hidangan harian mereka adalah seimbang. Kajian yang dilakukan menunjukkan bahawa peratus tertinggi ialah sebanyak 54 peratus setuju dan peratus terendah pula menunjukkan sebanyak lima peratus tidak setuju. Hal ini demikian kerana dengan penjagaan kesihatan mereka dapat menikmati tempoh jangka hayat lebih lama dan masalah kesihatan kronik dapat dielakkan. Sebanyak 31 peratus setuju bahawa ahli keluarga mereka tiada yang berpenyakit kronik sebagai contoh kencing manis, darah tinggi, sakit jantung, barah dan lain-lain lagi. Walau bagaimanapun, sebanyak 11 peratus responden menyatakan tidak pasti. Penjagaan kesihatan dapat melahirkan keluarga yang sihat di mana setiap keluarga tersebut mengamalkan atau fokus kawalan kesihatan dalaman sebagai contoh pengawalan kebersihan diri, dari segi pemakanan dan lain-lain lagi (Amran et al., 2012). Oleh itu, amalan kesihatan keluarga dapat melahirkan keluarga yang sihat dan makmur.

Selain itu, amalan kesihatan keluarga bebas daripada masalah penyalahgunaan dadah juga memainkan peranan penting dalam sesebuah keluarga. Hal ini demikian kerana amalan kesihatan yang ditekankan dalam keluarga menjadi kayu ukur bagi melahirkan sebuah keluarga yang seimbang, cemerlang dan sakinah (Sukemi et al., 2021). Kajian yang dilakukan menunjukkan bahawa sebanyak 62 peratus tertinggi responden menyatakan sangat setuju bahawa keluarga mereka bebas daripada masalah penyahlahgunaan bahan seperti dadah, alkohol, gam, daun ketum, ganja dan lain-lain. Walau bagaimanapun, sebanyak dua peratus sangat tidak setuju dengan kenyataan tersebut. Menurut Ismail et al. (2018) dalam sesebuah keluarga perlu mempunyai hubungan yang baik antara satu sama lain. Hal ini demikian kerana, tingkahlaku jenayah ahli keluarga akan memberi kesan kepada individu lain yang berada di persekitaran keluarga (Collins et al., 2007). Oleh itu amalan kesihatan keluarga perlulah mempunyai hubungan persekitaran yang baik antara satu sama yang lain.

Seterusnya, amalan kesihatan keluarga dapat meningkatkan kualiti hidup dalam sesebuah keluarga. Menurut Hyun dan Kyoung (2018), melalui penetapan program senaman semaksimum 
yang boleh, akan membawa perubahan tingkah laku dan peningkatan kualiti hidup warga tua. Malahan, dengan meningkatkan aktiviti fizikal dan mental warga tua melalui pergerakan fizikal yang teratur dan sistematik dapat meningkatkan kualiti kesihatan terutamanya kepada warga tua. Berdasarkan kajian, responden menyatakan kurang pasti dengan kenyataan bahawa keluarga mereka bersenam sekurang-kurangnya tiga kali seminggu iaitu 43 peratus. Manakala peratus terendah pula menunjukkan sebanyak enam peratus sangat tidak setuju dengan kenyataan berkenaan. Menurut Feaizul et al. (2019) amalan gaya hidup seperti bersenam dapat meningkatkan kualiti hidup seseorang. Malahan dengan bersenam juga dapat meningkatkan kepadatan tulang. Oleh itu pendapat ini jelas menunjukkan bahawa dengan melakukan senaman adalah salah satu menyumbang kepada peningkatan amalan gaya hidup yang sihat.

\section{Kesihatan umum}

Penjagaan kesihatan terutamanya warga tua akan menggalakkan peningkatan jumlah penuaan di sesebuah negara. Sebanyak 45 peratus tidak setuju bahawa dengan kenyataan warga tua ini kurang tidur kerana risau. Walau bagaimanapun, sebanyak dua peratus responden sangat setuju dengan kenyataan. Hal ini demikian kerana mereka tidak perlu memikirkan masalah yang dihadapi dan ini menyebabkan mereka sentiasa tenang. Malah mereka akan berfikir secara positif dan meneruskan kehidupan seperti sedia kala. Warga tua ini tidak akan mengatakan diri mereka tidak berguna. Sebanyak 52 peratus responden tidak setuju bahawa diri tidak berguna. Malah berdasarkan kajian yang diperoleh didapati hanya dua peratus menyatakan sangat setuju bahawa diri tidak berguna. Berfikiran positif akan menjadikan persekitaran sosial mereka lebih baik. Kajian yang dilakukan di Pakistan menunjukkan seseorang yang hidup dalam persekitaran sosial di mana dianggap orang tua secara positif cenderung mengembangkan harapan positif mengenai usia tua mereka (Malik et al., 2016). Hal ini menunjukkan warga tua ini tidak akan merasa mereka tidak berguna dalam kehidupannya apabila persekitaran sosial mereka dalam keadaan yang baik dan positif. Malah warga emas yang kurang interaksi sosial akan menyumbang kepada masalah kesepian atau berseorangan (Wiyono \& Djutaharta, 2019).

Seterusnya, meningkatkan kemampuan penjagaan proses mental aktif terutamanya kepada golongan warga tua atau warga emas ini perlu ditingkatkan. Hal ini demikian kerana, senaman dan mempelbagaikan aktiviti kepada warga emas dapat merangsang otak mereka (Marianna \& Lucia, 2019). Sebanyak 65 peratus menyatakan setuju bahawa warga emas dapat menikmati aktiviti harian dan sebanyak tiga peratus menyatakan tidak setuju. Menurut Sarin et al. (2018) bagi melahirkan warga emas yang produktif dan aktif, kepelbagaian aktiviti memainkan peranan yang penting. Sebagai contoh menyertai program rekreasi, program mendengar ceramah kesihatan, program latihan atau kursus dan lain-lain lagi. Hal ini menunjukkan bahawa kesemua aktiviti ini memberi peluang kepada warga emas untuk menjalankan aktiviti seharian mereka malah penglibatan warga emas dengan komuniti setempat. Oleh itu, aktiviti seharian ini memberi manfaat kepada warga emas terutamanya menjadikan warga emas yang aktif dan produktif,

Warga tua atau warga emas ini dapat menjalankan sebarang aktiviti mereka dengan baik dan lancar walaupun pergerakan mereka sedikit lambat. Walau bagaimanapun, mereka akan sentiasa gembira dalam apa jua keadaan. Kajian dilakukan menunjukkan bahawa sebanyak 57 peratus setuju bahawa dalam apa jua keadaan, mereka masih berasa gembira dan sebanyak tiga peratus menyatakan tidak setuju dengan kenyataan tersebut. Kajian yang dilakukan oleh Granerud et al. (2017) menyatakan jika seseorang kurang berfikiran perkara yang bukan-bukan akan memberikan kebaikan kepada warga tua, mereka akan rasa lebih sihat dalam kehidupan seharian 
mereka, malah sebilangan besar dari mereka telah mengamalkan sikap positif melalui kehidupan dan mereka akan merasa puas dengan kehidupan mereka. Walaupun ketika kesihatan fizikal merosot, mereka akan menyimpang perasaan tersebut. Oleh itu menunjukkan bahawa mereka akan sentiasa gembira dalam kehidupan seharian walau apa jua keadaan.

\section{Kesimpulan}

Proses penuaan merupakan proses semula jadi yang akan berlaku di sesebuah negara. Pada tahun 2035 akan berlaku tsunami kepada kepadatan penduduk warga tua di Malaysia apabila berlakunya peningkatan bilangan warga emas yang berumur 65 tahun. Peningkatan penyediaan perkhidmatan khusus kepada warga tua akan terus meningkat dalam fenomena ini dan isu sosial juga akan bertambah. Hal ini secara tidak langsung akan mempengaruhi kesihatan warga tua di Malaysia. Walau bagaimanapun, kesedaran warga emas terhadap kemudahan kesihatan, amalan kesihatan dan kesihatan umum adalah pada tahap yang sederhana. Oleh itu badan kerajaan mahupun bukan badan kerajaan perlu memberi fokus utama kepada warga tua. Dasar kesihatan awam pada masa hadapan perlu diberikan perhatian bersesuaian dimensi dalam reka bentuk dan pelaksanaan, penyesuaian cadangan perubatan dalam setiap konteks. Sebagai contoh pihak kerajaan atau badan bukan kerajaan boleh mengadakan program-program atau latihan kepada pekerja sosial, doktor, jururawat dan penjaga warga emas dalam meningkatkan kesejahteraan dan kualiti hidup warga emas.

\section{Penghargaan}

Penghargaan kepada Geran Penyelidikan FRGS/1/2019/SS07/UKM/02/2 kerana membiayai sepenuhnya penyelidikan dan penerbitan ini, dan banyak memberi pertolongan dalam memantapkan penyelidikan dalam pelbagai aspek.

\section{Rujukan}

Ahmad Shukri, A. H., \& Norliza, M. (2018). Malaysia menuju negara tua: Apakah yang boleh dipelajari daripada pengalaman negara Jepun? Human Sustainability Procedia (INSAN 2018 E-Proceeding), 406-419.

Alice, S. I., Shahida, A., \& Fadhlina, A. T. (2019) The effectiveness of public facilities in low cost housing flats from residential satisfaction towards sustainable living. Asia Procedding of Social Sciences, 5(1), 1-6.

Amran Hassan, Fatimah Yusoof \& Khadijah Alavi. (2012). Keluarga sihat melahirkan komuniti sejahtera: Satu Ulasan. Geografia-Malaysia Journal of Society of Space, 8(5), 51-63.

Anon. (2015). Cabaran negara tangani masyarakat warga tua. Malaysiakini. Diperoleh daripada https://www.malaysiakini.com/news/294177, 21 April 2020.

Azura, T., \& Suresh, K. N. V. (2019). Warga emas dan pilihan penempatan di pusat jagaan harian. Journal of Social Sciences and Humanities, 16(4), 1-22. 
Berstad, P., Botteri, E., Larsen, I. K., Loberg, M., \& Kalager, M. (2016). Lifesyle changes at middle age and mortality: A population base prospective cohort study. Journal of Epidemiology and Community Health, 71(1), 59-66.

Bose, M., \& Banerjee, S. (2019). Equity in distribution of public subsidy for noncommunicable diseases among the elderly an application of benefit incidence analysis. BMC Public Health, 19, 1735.

Cell Proteomics. (2007). Toward a comprehensive atlas of the physical interactome of saccharomyces cerevisiae. US National Library of Medicine National Institutes of Health, 191-215.

Collins, R. L, Ellickson, P. L., McCaffrey, D., \& Hambarsoomians, K. (2007). Early adolescent exposure to alcohol advertising and its relationship to underage drinking. Journal of Adolescent Health, 40, 527-534.

Escamilla, V., Calhoun, L., Odera, N. \& Speizer, I. S. (2019). Access to public transportation and health facilities offering long-acting reversible contraceptives among residents of formal and informal settlements in two cities in Kenya. Reprod Health, 16, 161.

Feaizul, M. D., Soh, K. G., Nurul, H. E., \& Siswantoyo, M. K. (2019). Analisis jumlah pengambilan kalori, kalsium dan protein serta hubunganya dengan kepadatan mineral tulang dalam kalangan warga tua. Malaysian Journal of Movement, Health \& Exercise $8(2), 81-98$.

Granerud, A., Imingen, I., \& Erikssin, B. (2017). Everyday life and wellbeing among the oldest elderly in Norway-A qualitative study. Open Journal of Social Sciences, 5, 97-111.

Heryanah. (2015). Ageing population dan bonus demografi kedua di Indonesia. Jurnal Kependudukan dan Kebijakan Universitas Gadjah Mada, 23(2), 1-16.

Huh, J-H., \& Kim, T. (2019). A location-based mobile health care facility search system for senior citizens. The Journal of Supercomputing, 75(4), 1831-1848.

Hyun, J. L. \& Kyoung, D. K. (2018). Effect of physical activity on cognition and daily living activities of the elderly with mild dementia. The Journal of Physical Therapy Science, 30, 428-433.

Idris Musa. (2017). Malaysia semakin berusia. My Metro. Diperoleh daripada https://www.hmetro.com.my/mutakhir/2017/09/263080/malaysia-semakin-berusia, $\quad 21$ April 2020.

Ismail, A. M., Ghani, A. R. A., \& Daud, M. N. (2018). Women in immoral issues and methods of building properous life. Journal Sains Humanika, 10(3-4), 155-163.

Jabatan Kebajikan Masyarakat. (2017). Dasar Warga Emas Negara. https://www.jkm.gov.my/jkm/index.php?r=portal/left\&id=WjFUdFBURTV0Zis0N0NxY m05Qk9XQT09.

Jinming, F., Ling, L., \& Pengqian, F. (2019). What is the most important factor affecting patient satisfaction - A study based ob gamma coefficient. Us National Library of Medicine National institutes of Health, 13(1), 515-525.

Kementerian Kesihatan Malaysia. (2016). Dasar Warga Emas Negara. https://fh.moh.gov.my/v3/index.php/31-kesihatan-warga-emas.

Khadijah Alavi \& Maizatul, H. M. (2017). Komunikasi berkesan dengan warga emas: Dari perspektif intervensi kerja sosial. Jurnal Komunikasi Malaysian Journal of Communication, 33(4), 21-37. 
Liqun, X., Ann, T. W. Y., Yongtao, T., Xuezhu, S., \& QiPing, S. (2019). Senior citizens' requirements of services provided by community base care facilities: A China study. Journal Facilities, 38(1/2), 52-71.

Malik, R.T., Ayaz, A., \& Bhutto, Z.H. (2016). Interrelation of perception of old age and respect toward old people among young adults. Bahria Journal of Professional Psychology, 15(2), 95-112.

Manang, F., \& Yamauchi, C. (2018). The impact of access to health facilities on maternal care use, travel patterns and health status: Evidence from longitudinal data from Uganda. The University of Chicago Press Journals, 2018, 1-55.

Marianaa, M. D. M., \& Lucia, R. (2019). Psychological bases of developing social competences of seniors with disability. Australian Journal of Adult Learning, 59(2), 269-292.

Mohd Farok, M. N., Nor 'Adha, A. H., Nur Zulfah M. A. S., Sharifah Hana, A. R., \& Mashitah, N. K. (2021). Kelangsungan kehidupan warga emas: Usaha kerajaan dan cadangan penambahbaikan. Dlm. Internatonal Conference on Syariah \& Law 2021 (ICONSYAL 2021), ms. 134-143. Diperoleh daripada http://conference.kuis.edu.my/iconsyal/images/ eprosiding/1021.pdf

Muhammad Nur, \& Hamid, M. (2020). Kualitas hidup ditinjau dari pengetahuan keluarga tentang perawatan lansia. Journal of Community Engagement, 3(1), 15-22.

Nunnally, J. C., \& Bernstein, I. H. (1994). Pychhometric Theory (3 ${ }^{r d}$ ed). New York: McGrawHill.

Nurhazirah, H. N., \& Khadijah, A. (2021). Meneroka kesejahteraan psikologi dan kualiti pusat jagaan warga emas di Selangor. Jurnal Psikologi Malaysia, 35(1), 87-97.

Qin Wang. (2019). Service design strategy of public information products for elderly users. Advances in Economics, Business and Management Research,110, 865-86.

Sarin, J., Khadijah, A., \& Mohd Suhaimi, M. (2018). Perbandingan tahap kualiti hidup bagi warga emas yang mendapatkan perkhidmatan di Pusat Aktiviti Warga Emas (PAWE) di kawasan bandar dan luar bandar. Jurnal Psikologi Malaysia, 32(3), 82-90.

Schulte, P. A., Guerin, R. J., Schill, A. L., Bhattacharya, A., Cunningham, T. R., Pandalai, S. P., Eggerth, D., \& Stephenson, C. M. (2015). Considerations for incorporating "well-being" in public policy for workers and workplaces. Am J Public Health, 105(8), 31-44.

Shaista, N., Filzah, M. I., \& Leilanie, M. N. (2019). Ageing care centre women entrepreneur: A silver bullet for ageing tsunami in Malaysia. Sains Humanika, 12(1), 51-62.

Siti, K., Joni, H., \& Hanik, E. N. (2019). Hubungan dukungan keluarga dengan kemandirian lansia dalam pemenuhan activitie daily living di Dusun Sembayat Timur, Kecamatan Manyar, Kabupaten Gresik. Indonesian Journal of Community Health Nursing, 2(2), 91-98.

Sukemi, M. N., Yusof, R., \& Sanisah, A. (2021). Program keluarga sakinah dan kesannya melalui persepektif ekonomi. Asian Journal of Environment, History and Heritage, 5(1), 41-51.

Takeshi, H., Nobuo, S., Hiroyuki, O., Akiko, O., Takafumi, S., Yuki, N., Shinsuke, O., Yuka, M. \& Satoshi, N. (2019). Intentional or unintentional drug poisoning in elderly people: Retrospective observational study in a tertiary care hospital in Japan. Acute Medicine \& Surgeri, 2019(6), 252-258.

Wiyono, N.H., \& Djutaharta, T. (2019). Pola pengaturan tempat tinggal (Living Arrangement) penduduk lanjut ssia: Studi kasus di Bali. Indonesia: Lembaga Demografi FEB, Universitas Indonesia.

Wong. R. Szeto. W., Yang. L., Li. Y. \& Wong. S. (2018). Public transport policy measures for improving elderly mobility. Journal Transport Policy, 63, 73-79. 